\title{
University Participatory Experience building Open Education Resources
}

\author{
Alcantara-Concepcion Tamara \\ Dirección de Innovación y Desarrollo Tecnológico, Dirección General de Computo y Tecnologías de \\ Información y Comunicación. Universidad Nacional Autónoma de México, Ciudad Universitaria \\ Circuito Exterior s/n, Coyoacán, Cd. Universitaria, Mexico City, México \\ talcantarac@unam.mx
}

Received date: 29 August 2017; Accepted date: 9 January 2018; Published date: 4 June 2018

Academic Editor: Mohammad Ayub Khan

Copyright (C) 2018. Alcantara-Concepcion Tamara. Distributed under Creative Commons CC-BY 4.0

\begin{abstract}
This paper has the objective to analyze the obstacles and opportunities of Universities knowledge construction throughout partaking process. In schools, teachers are the main knowledge trigger, not only producing and transmitting new knowledge, but also integrating new technologies in classrooms. Teachers' participatory model to construct educational resources is proposed. Nowadays universities face the challenge to utilize Information and Communication Technology (ICT) tools in classrooms as part of day after day teaching-learning processes. Currently, there are available virtual learning objects, educational platforms, interactive systems besides others. However, universities curricula need to cover a big quantity of topics and not all of them has been enclosed, or has the quality, level and language required by each course.This paper also describes the recent experience of building educative resources following open resource philosophy. The construction of the Learning University Network (RUA for its Spanish acronym) by Mexican teachers has been documented. The processes comprise to assemble, to organize and to institutionalize Open Educational Resources with a unified criterion. At the end of the paper, the procedures to conform Open Educative Resources related to UNAM Curricula have been structured. The generated knowledge in RUA building should be useful to new experiences in further institutions.
\end{abstract}

Keywords: ICT, Online Educative Resources, Participatory Processes, Teaching and Learning Process.

\section{Introduction}

In the last years, there has been a vertiginous growth in developing and integrating Information and Communication Technologies (ICT) into Teaching and Learning practices. Knowledge Initiatives arose, impacting diverse levels of activity, for instance, it is possible to find ICT developments to support how to manage a full school or university or very specific learning objects; complex platforms as Moodle, Sakai, Blackboard among others have been developed, as consequence of distance education evolution.

Cite this Article as: Alcantara-Concepcion Tamara (2018)," University Participatory Experience building Open Education Resources ", Journal of e-Learning and Higher Education, Vol. 2018 (2018), Article ID $71250 \mathrm{nn} \mathrm{nI} \cdot 1 \mathrm{n} 5171 / 20187125 \mathrm{n}$ 
At the beginning of distance education systems, there were correspondence, cassettes and magazines distance courses, and later CDs. Even more, basic education in homeschooling modality with special books and certifications appeared since 1950s decade (Courtenay, 2011). Currently, ICT incorporation into education processes allow complex, flexible and interactive tools. ICT permit immediate information interchange and efficient communications, facilitating teachinglearning processes.

In the other hand, virtual education resources proliferation has not been enough. Now, it is possible to find a wide variety of this kind of resources in the World Wide Web, however not all topics of knowledge have related resources, there are different levels of developing. In consequence, it is possible to find conventional documents, books or journals; but some resources have been developed in very complex way. Some resources are very complex, with text, hyperlinks to navigate, evaluation and feedback, but it could be difficult to integrate digital resources into comprehensive curricula of schools or universities.

This paper is around the next research questions: How to develop reliable digital education resources related to big quantity of knowledge subjects? Is it possible to utilize participatory mechanisms to build complex resources as a community? The Mexican University case is shown as an experience of participatory process approach to answer these questions.

\section{Literature Review}

Teaching and learning processes characteristics, methods and efficiency has been discussed throughout human history. Some periods and societies education was only for rich or religious people; in many cases small or individuals' interaction with teachers. Education in ancient Greece was regarded as an essential component of a person's identity and the type of education a person received was based strongly on one's social class and the culture of one's poli (Gvelesiani \& Javakhishvili, 2013).

Education challenges have multiple aspects to deal with, for instance: the quality of knowledge and its transmission, inequity access conditions to acquire knowledge, high costs, lack of infrastructure and educators, and high rates of demand (Kremer, et al., 2013), (OECD, 2012).

\section{Learning Theories}

Diverse authors since 1950's decade have proposed theories and models to understand individual and organizational learning. Each of them has identified variables that affect the way people learn and make decisions. Table 1 , shows some of the main theories.

Table 1: Learning Theories

\begin{tabular}{|c|c|c|}
\hline $\begin{array}{l}\text { Learning } \\
\text { Theory }\end{array}$ & Brief description & Reference \\
\hline $\begin{array}{l}\text { Theory of } \\
\text { cognitive } \\
\text { dissonance }\end{array}$ & $\begin{array}{l}\text { Human adjusts actions in function of new elements } \\
\text { of cognition, having one of next behaviours in the } \\
\text { reality: } \\
\text { - Consonant actions and beliefs } \\
\text { - Cognitions or actions irrelevant to each } \\
\text { other } \\
\text { - Cognitions inconsistent with actions }\end{array}$ & (Festinger, 1957) \\
\hline $\begin{array}{l}\text { Cognitive, } \\
\text { Affective and } \\
\text { Behavioral } \\
\text { Components of } \\
\text { Attitudes }\end{array}$ & $\begin{array}{l}\text { Individual situations, social issues and other stimuli } \\
\text { incites attitudes that can be measured as: } \\
\text { - Affect - Sympathetic responses } \\
\text { - Cognition - Perceptual responses } \\
\text { - Behavior Components - Actions. }\end{array}$ & $\begin{array}{l}\text { Rosenberd and } \\
\text { Hovland, } 1960 \text { in } \\
\text { Freisbend, } 1973 \\
\text { (Fishbein \& Ajzen, } \\
\text { 1975) }\end{array}$ \\
\hline
\end{tabular}




\begin{tabular}{|c|c|c|}
\hline $\begin{array}{l}\text { Theory } \\
\text { Reasoned } \\
\text { Action. }\end{array}$ & $\begin{array}{l}\text { To understand the factors that continuously affect } \\
\text { an active participation it is needed to analyze: } \\
\text { - The behavior is product of the individual beliefs; } \\
\text { - To get a change, the information received by } \\
\text { individuals and its acceptation will facilitate the } \\
\text { change and participation level. }\end{array}$ & $\begin{array}{l}\text { (Fishbein \& Ajzen, } \\
\text { 1975) }\end{array}$ \\
\hline $\begin{array}{l}\text { Social Learning } \\
\text { Theory }\end{array}$ & $\begin{array}{l}\text { Human behavior must be described by a model built } \\
\text { accomplished through observations. }\end{array}$ & (Bandura, 1977) \\
\hline $\begin{array}{l}\text { Adapted } \\
\text { Theory } \\
\text { Reasoned } \\
\text { Action }\end{array}$ & $\begin{array}{l}\text { Introduces the study of impact on intention from } \\
\text { external variables, as demographic and personality } \\
\text { among others. }\end{array}$ & $\begin{array}{l}\text { (Crosby \& } \\
\text { Muehling, 1983) }\end{array}$ \\
\hline $\begin{array}{l}\text { Organizational } \\
\text { Learning }\end{array}$ & $\begin{array}{l}\text { Describes organizational level of learning, and } \\
\text { interchanging among individuals and the } \\
\text { organization. Emphasize errors detections } \\
\text { capabilities. }\end{array}$ & (Argyris, 1992) \\
\hline $\begin{array}{l}\text { Theory of } \\
\text { Planned } \\
\text { Behavior }\end{array}$ & $\begin{array}{l}\text { Links beliefs and behavior. Main premise is that a } \\
\text { person will perform a behavior if he believes in the } \\
\text { advantages of success. } \\
\text { Some researchers reject it outright as an adequate } \\
\text { explanation of human social behavior. These } \\
\text { investigators tend to deny the importance of } \\
\text { consciousness as a causal agent (Wegner, 2002; } \\
\text { Wegner \& Wheatley, 1999) }\end{array}$ & $\begin{array}{l}\text { (Ajzen, From } \\
\text { intentions to } \\
\text { actions: A theory of } \\
\text { planned behavior. , } \\
\text { 1985) }\end{array}$ \\
\hline $\begin{array}{l}\text { Double Loop } \\
\text { Learning } \\
\text { Theory }\end{array}$ & $\begin{array}{l}\text { About individual learning, and how experience can } \\
\text { modify the goals, objectives or decision choices. } \\
\text { First loop following rules, second loop adjusting } \\
\text { goals. }\end{array}$ & $\begin{array}{l}\text { (Argyris, Single } \\
\text { and double loop } \\
\text { models in research } \\
\text { in decision making, } \\
\text { 1976) }\end{array}$ \\
\hline $\begin{array}{l}\text { Five } \\
\text { Disciplines }\end{array}$ & $\begin{array}{l}\text { Proposed five competences to build a learning } \\
\text { organization: Systems approach, individual } \\
\text { mastering, changing individual and organization } \\
\text { mental models, motivate learning, sharing same } \\
\text { vision than organization, increasing problem } \\
\text { solving capacity, conforming teams to learn and } \\
\text { share the knowledge. }\end{array}$ & (Senge, 1990) \\
\hline $\begin{array}{l}\text { Knowledge } \\
\text { Creating } \\
\text { Company }\end{array}$ & $\begin{array}{l}\text { Knowledge creation is present when an } \\
\text { organization generate and disseminate, } \\
\text { intentionally, knowledge that enables or allows } \\
\text { developing new products or modifying current } \\
\text { processes. The author sustains the existence of two } \\
\text { kinds of knowledge: tacit and explicit. }\end{array}$ & $\begin{array}{ll}\text { (Nonaka } & \& \\
\text { Takeuchi, 1995) } & \end{array}$ \\
\hline $\begin{array}{l}\text { Knowledge } \\
\text { management }\end{array}$ & $\begin{array}{l}\text { KM Model has three phases: Generate, Codify, and } \\
\text { Transfer Knowledge. Later, Davenport affirmed that } \\
\text { only humans generate knowledge, in consequence, } \\
\text { computers by itself are not enough to produce } \\
\text { knowledge. }\end{array}$ & $\begin{array}{l}\text { (Davenport \& } \\
\text { Prusak, 2000) } \\
\text { (Davenport, 2005) }\end{array}$ \\
\hline $\begin{array}{l}\text { Knowledge } \\
\text { management } \\
\text { Cycle }\end{array}$ & $\begin{array}{l}\text { European Committee for Standardization, showed } \\
\text { five core activities of knowledge: Identify, Create, } \\
\text { Storage, Share and Use. }\end{array}$ & (CEN, 2004) \\
\hline $\begin{array}{l}\text { Communities } \\
\text { of practice }\end{array}$ & $\begin{array}{l}\text { It is based in how to acquire specific knowledge } \\
\text { over sharing information and experiences. }\end{array}$ & (Wenger, 2010) \\
\hline
\end{tabular}




\section{E-learning}

E-Learning is an electronic education system or distance program that integrates ICT and didactic elements to teach and train students on-line, in other words, the system is based on knowledge acquisition within electronic media. E-Learning is a distance education modality (EcuRed, 2015).

At UNAM, specialized E-Learning courses situated on-line education advantages and disadvantages, when it is utilized a whole educative system, for instance an educative platform (CUAED-UNAM, 2012-1016):

E- Learning is the elimination of distance and time barriers, and the permanent availability of virtual resources and communication media as forums, chats, videoconferences, e-mails, blogs, social networks, slides presentations, books, journals and magazine, wikis and others. Assessors can be present or not. Their benefits are: that content changes and managing are easy to control, systems are flexible to add or change contents and times to adapt it according to didactic requirements, organizing information, supervising, evaluating and feed backing constantly and individualizing is possible. Also, stakeholders of the systems can enhance communications among them and with similar institutions. It is possible to share digital resources with similar courses or sessions.

In counterpart, some challenges detected using virtual educative resources are: that it is necessary to obtain reliance, trust and available for each study level. In other plane, teachers must utilize educative resources with knowledge, not only about the subject of the course, but also about differences among face to face, semi-face to face and distance courses, considering furthermore the ICT skills. Even more, it is indispensable to integrate pedagogic approaches, ICT knowledge and psychological profiles. Adding to the requirement of infrastructure available for students and teachers as other critical factor, particularly in countries or zones with economical insufficiency. Same point with the norm to have access into virtual educative resources,

In their study, Everlyn Kahiigi and coauthors conclude that there are two problems in e-learning implementation within the higher education context (Kahiigi, et al., 2008):

1) the limited uptake of technology as an instruction delivery method; and

2) the ineffective use of technology to support learning.

\section{Educative challenges}

Educative international organizations, like the UNESCO, already worked and developed studies about the obstacles and advantages on the use of ICT in education (UNESCO, 2008; OCDE, 2017). For instance, it is relevant to mention an OCDE study that shows four forces of change that will impact on high level education systems over the next decades (OCDE, 2017); those forces are:

- Globalization: The curricula will be internationalized, impacting in two ways: by increasing the pair to pair collaboration and by increasing the competition.

- Demography: Countries belonging to OCDE registered reductions in the traditional 18-to-25-year-old student group will affect institutions. On the other hand, countries that do not belong to OCDE have also increased their education demands. Those demands are currently not fully covered; even more, there is an increase in educative demands among higher age groups. Mostly all countries are increasing their participation on higher education levels; and that demands are not overcome to date.

- New government forms: There are strong demands to improve public administrations. Lately, there is an increase in all educative institutions to improve their areas 
in: Accountability, transparency, efficiency and effectiveness, responsiveness and forward vision. All those components are now considered of primordial importance to assure good public governance.

- Technologies: ICT developing an innovation that has a large impact on education, but not in the expected magnitude. In contrast, elearning does have a great potential; even when, to date, there are not monitoring studies. Institutions like the OCDE assure that there is an important increase in the number of students that opt for virtual environments.

On the other hand, the use of participatory virtual technologies, like Creative Commons and Web 2.0, to build digital contents does have rapid increase rates. This increase is mainly due to the increase of broadband and new software tools.

\section{Mexico and Education}

Organization for Economic Co-operation and Development in Panorama 2017 study showed Mexican High Education Institutions that have an insufficient capacity to face up to the student's education demand. Among others, study concludes only $16.8 \%$ people aged among 25-64 years-old who received a university degree (OCDE, 2017).

To have quality attention, it is necessary to generate new ways to spread knowledge. ICT are offering, to general societies, more and more opportunities. The developed Virtual Systems enable easier productive and social processes. Teaching-Learning Systems are not far of that changes, organizations as UNESCO have formulated studies about the advantages and disadvantages (UNESCO, 2008), however in Mexico, there is not an accurate analysis of the situation and future actions to get teachers assimilation of ICT tools.

\section{Open Educative Resources}

Due to editorial and distribution costs - and the business model of traditional editorials - many scientific journals started charging the authors with a publication fee. The cost of scientific journals implied a barrier, especially for scientist in the third world. Even more, the mandatory research copyright cession, in favor of the editorial even with fees for the author of the manuscripts - was the origin of a movement. Such movement, called Open Access, started mainly in the USA, but quickly spread on many countries. Peter Suber defines Open Access as; the movement that has the goal to assure the openness and freedom of scientific information to anyone. The academic activities supporting this idea started around 1966, spreading widely since then (Peter Suber, 2009).

While UNESCO has published the definition of Open Educative Resources (OER) as learning, teaching and research material deposited in the public domain or published under an intellectual property license that allows their free use, adaptation and distribution (UNESCO, 2017). Resources can be learning objects, full courses, simulations, manuals, books, and many other documents related to education and knowledge.

\section{The Participatory Planning Approach Applied to the Education Process}

Participatory planning definition is: to build a desired future for a given system with all the involved people's actions and opinions. This approach is common when doing interventions of social organizations. Some advantages of this approach over the people involved are that:

- $\quad$ They assume the plan's ownership and act consequently

- They know the system and it's interactions; so, there is high confidence and reality when analyzing and collecting the data.

- They are a critical mass, with capacity of providing ideas and solutions in a wide variety of ways, 
including plenty knowledge of the today state and the past of the system.

- Many obstacles usually generated by the community on the system are overcome.

As Ming Sum and colleagues said: several studies on participatory process in education are focused on the students' participation (Ming-sum, T.B.K. et al, 2005 y Kucharčíková, A, 2016). This approach is straightforward for the education process since mostly all learning and teaching processes want to improve the students' capabilities and the enabling media to reach the goal are basically the professor and the information and knowledge, including the mechanisms teachers decide to transfer.

In education, there is the collaborative learning concept. Developed by Vigotsky in the nineteen seventies, this concept is defined as: the learning organization thru interaction of pairs (Vigotsky, 1978). An important group of efforts is well documented to set collaborative models; for instance, the Badia job about: Learning through project' making and ICT (Badia, 2006). Most of these efforts are focused on facilitating the interaction among administrators and users thru technological tools.

Other projects, related to collaboration, are those that incorporate a specific ICT to stimulate collaboration. One example is given by Koschman, it is called: "Computer Supported Collaborative Learning" (CSCL); that is collaborative learning based on technologies for educative interaction (Koschmann, 1994). Also, Raidell Avello conducted a study focused on different sorts of ICT and their impacts when doing collaborative learning (Avello, 2016). Therefore, current collaboration research is mainly centered on the classroom and among students.

Despite the central role of teachers, the projects are not including in a systematic way the efforts from professors and researchers on the design and making ICT tools for learning, nor when building and electing tools during the teaching and learning process.

The system presented in the next section, focuses on encouraging teachers' participation during the digital resources building, associated with the UNAM curricula. From the pedagogic stand point, teachers' participation is critical, due to their role as designers of the learning objectives, contents and dynamics on the day to day class. The other part of this teachers' role; that is assuring participation of all the elements related to the teaching and learning process, is key when building tools. The main goal is to build the ICT according to the educative needs on each phase of the process, to have them evaluated and then to make them put in practice in the classrooms.

\section{The Learning University Network Macro- System Analysis}

Figure 1 shows the background of Learning University Network (RUA by its acronym in Spanish) within the main components of its macro-system: National Autonomous University of Mexico (UNAM). As a support to the system, infrastructure has a fundamental role; academic activities at UNAM included education from the equivalent to High school to postgraduates, continuing education courses, and seminars. Those activities are conducted in an area over 2,815,591 $\mathrm{m}^{2}$. That zone represents 2,183 buildings. The distribution of educative levels across the buildings is:

- University education: 15 departments, 5 multidisciplinary units and 5 National Schools.

- High Schools: 14 units.

- Research Institutions: 33 Institutes, 15 research centers, 10 university programs.

Over time, ITC have been included at all levels of the university, not without great efforts. By 2017, the UNAM has:

- 78,233 computers, all with Internet connection. 
- 138,635 active accounts in the University Wireless Network.

- $\quad$ Supercomputing abilities, with 228 billion arithmetic operations per second.

Despite the large computer's amount, the numbers are not enough, considering that the UNAM's population is constituted by 349,539 students and 40,184 academics, for the year 2016-2017.

The University does have 120 academic programs at university level, with 208 educative options, 92 graduate programs (master's and doctorate), 3 high school programs, and 35 technical programs among 5 areas: Social Sciences, Biological Sciences, Chemistry and Health Sciences, Physics and Mathematics, Humanities and Arts. In this setup, teachers are continually generating educative resources, practices, strategies, interactive systems, simulations, test questions, evaluations, and many other educative resources. The amount of materials is increasing constantly and keeping track of all of them is not easy; but for instance, UNAM published a total of 1,944 books in electronic and hardcopy formats, just for 2016.
On the other hand, in México, there are several approaches oriented to make all publicly funded scientific information freely available, without any restrictions. In particular, the "Ley de Ciencia y Tecnología, Artículo 65, Capitulo X. Del Acceso Abierto, Acceso a la Información Científica", Tecnológica y de Innovación y del Repositorio Nacional (Science and Technology Law, article 65, chapter X, Regarding Open Access, Scientific, Technological, Innovation and National Repository Information Access) (H. Congreso de la Unión, 2014). Besides the UNAM's adhesion to this law, the institution has joined the Berlin declaration, whose mission is: "to support new knowledge possibilities, not only in the classic way, but using the open access paradigm, through the use of internet. We define open access as an extensive human knowledge source and as a cultural heritage approved by the scientific community "(Open Access 2003). Accordingly, UNAM has included open access and freely available resources through its own plans and programs since 2011 (UNAM 2011, 2015). 


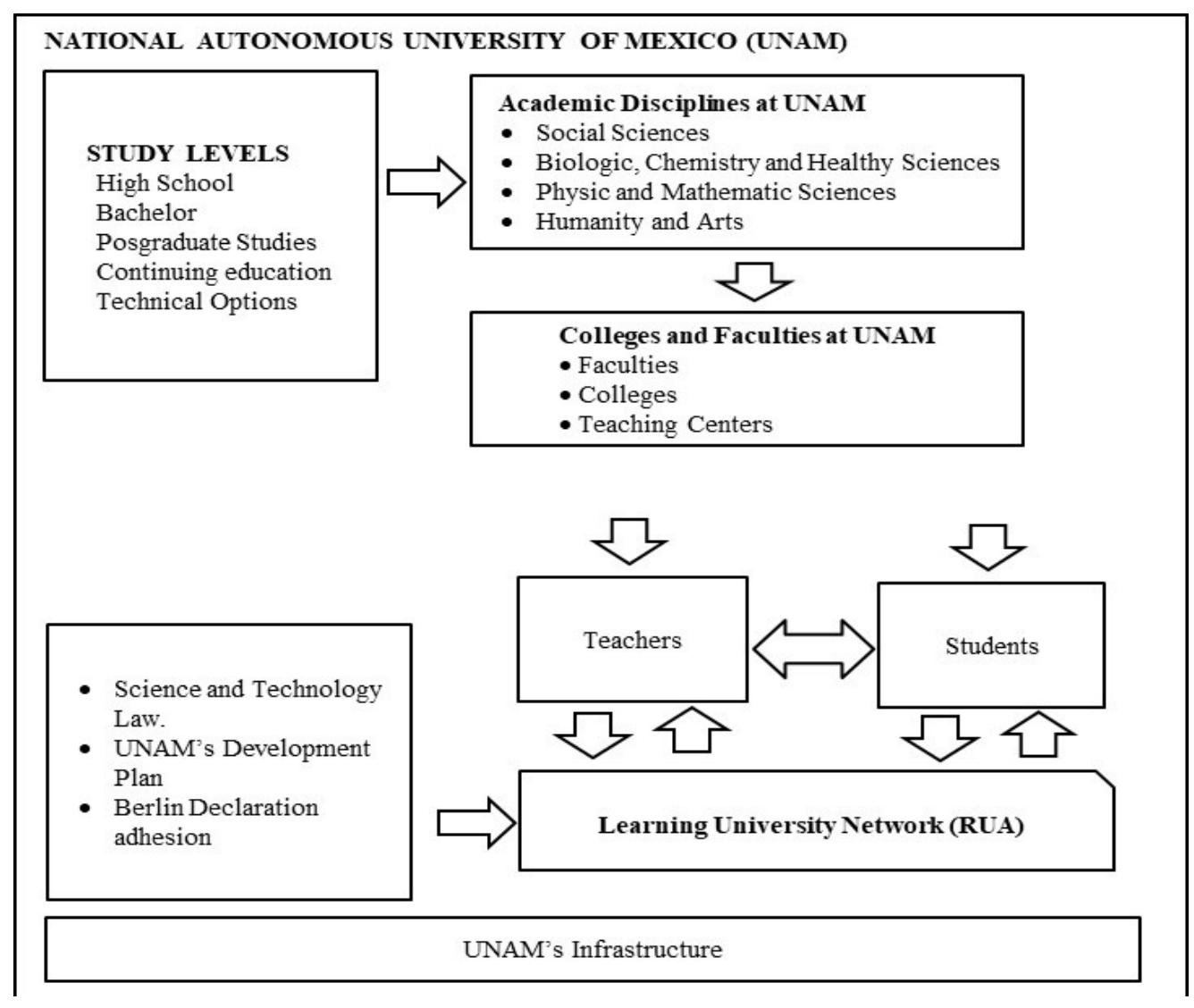

Figure 1: Learning University Network (RUA) Macrosystem.

Many individual and institutional efforts have been done to make all UNAM information completed with public resources, available and free to the members of the university and to the public. Among other efforts, an Open Educative Resources initiative appeared: The Learning University Network.

\section{The System: Learning University Network}

Felipe Bracho said: Learning University Network (RUA) is a cooperative institutional effort (Bracho 2017). The RUA started in 2011 and it is a virtual mechanism to hold Open Education Resources (OER). While, Castillejos added: the RUA goal is to give teachers easy access to all materials related to the UNAM curricula. Materials included in the RUA are generated by the UNAM or other university authors.
To date, the program "Toda la UNAM en linea" is the initiative that holds all the institutional efforts to publish open access information. The RUA is part of those efforts, but focused on educative resources (Castillejos et al, 2016).

The RUA is currently ministered by the Dirección General de Cómputo y Tecnologías de Información y Comunicación (DGTIC). Many OER, focused on the university programs, have been published by DGTIC under the RUA, at least until 2016. A summary of the number of OER published is:

\footnotetext{
- Iniciación Universitaria (University Initiation Program): 1,649

- $\quad$ Escuela Nacional Preparatoria (ENP, High School): 5,735
} 
- Colegio de Ciencias y Humanidades (CCH, High School): 4,230

- $\quad$ Bachelor programs: 3,700

- General interest subjects: 1,033

Nowadays, RUA contains different kinds of OER, as documents, books, apps, Web pages among others. All OER has been reviewed by Academic Commit, and classified by school, semester, subject and themes, each of them with subdivision:

- Knowledge you must to knew

- Learning Resources for the topic

- Self-evaluation

- Teacher's resources

- Additional resources.

To date, DGTIC has been focused mainly on High School programs: CCH and ENP. High school OER about almost all the courses are already published. Therefore, the RUA is offering a group of advantages. According to Castillejos, advantages to the teachers include (Castillejos et al, 2016):

- $\quad$ All OER can be used any time and everywhere.

- All members of the university have the possibility of publishing their own materials.

- Current participation channels are enhanced to all university members.

- The society has now high quality and resourceful OER.

- $\quad$ RUA is an institutional media to review and spread OER.

- $\quad$ All repositories with learning objects have high growing rates; this opens the door for automatic interchange among digital libraries and systems to educative applications.

And for the students:
- $\quad$ To motivate, awake, and keep interest about the subjects.

- $\quad$ To serve as a learning guide to the students

- To evaluate knowledge and abilities

- To increase the learning opportunities

- To promote independent learning

- To speed up the study time

- To ease the access for learning materials without restrictions

- To get information about each course, including the syllabus and activities for each subject.

- To keep track about antecedents and follow ups on each subject

\section{RUA's Working Processes and Participation Mechanisms}

Figure 2 includes the main processes, actors and activities needed to build, evaluate and divulgate OER. The efforts are focused to achieve the ITC incorporation to the educative process as efficient, effective and useful tools, capable to transmit abilities and knowledge at UNAM.

Therefore, the RUA has been designed and built according to the current Mexican laws and following international agreements regarding publishing research and teaching findings. Findings include all scientific, technological, and innovation data, already included in the strategic program "Toda $l a$ UNAM en Línea", since 2011. This strategic program is the fundamental stone that sustain all RUA's activities.

Five central processes to build the RUA are shown in Figure 2. Each process is linked to a responsible actor. Each actor oversees conducting or makes possible the task, shown in the top of each process. All products and results are described in the lower part of each process. Relevant issues and characteristics are described in the lower section. 


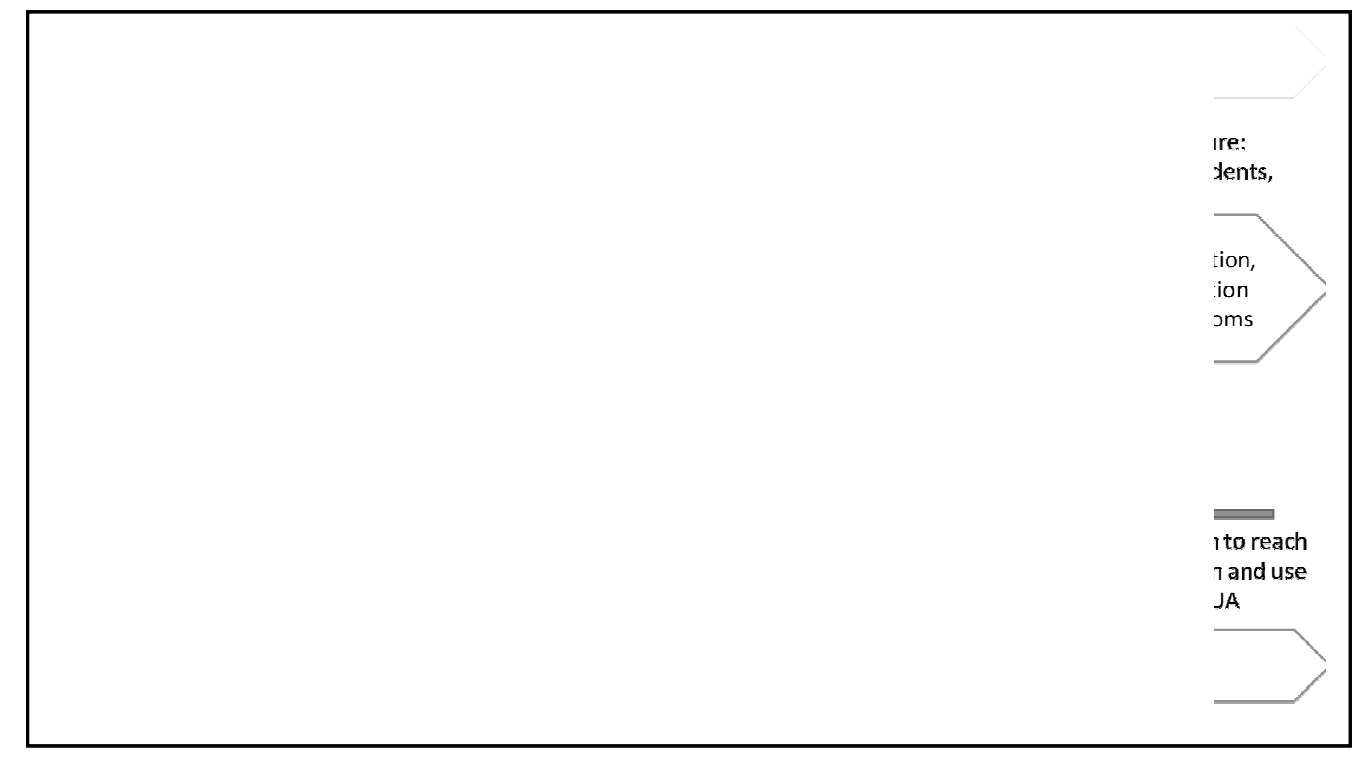

Network. Own elaboration, based on internal working documents and personal interviews with Dirección General de Cómputo y Tecnologías de Información y Comunicación (DGTIC) employees (UNAM, 2016).

Each process implies large efforts and the need of involvement from authorities and professors. Included process and interactions to achieve community participation are:

\section{Call for participation on developing digital resources.}

The call for participation has been linked to the Programa de Apoyo a Proyectos para la Innovación y Mejoramiento de la Enseñanza, (Program to Support the Innovation and Enhancement Education Projects, PAPIME)" under the ministration of the Dirección General de Asuntos del Personal Académico (Direction of Academic Employment Subjects, DGAPA). Each year, the PAPIME is funding projects that propose building manuals, programs and digital applications, associated with the curricula and focused on strengthening the learning and teaching schemes (DGAPA, 2017). Independently from this call for participation, all university instances, teachers and researchers that develop or have developed their own materials are constantly invited to share them through the RUA.

The only request is that all resources must be published and developed using free technologies, without restrictions, with free copyrights and, with preference, to be interactive. There is not a predefined format, so, any document, practice, simulation, or game that is linked to the UNAM curricula can be included freely.

DGTIC on their own is offering scholarships to teachers focused to achieve a RUA certification. This 180 hours' course, given to UNAM professors, is called "Digital resources for didactic planning" (UNAM, 2016).

This task is conducted by the professors, who add their knowledge and expertise when giving courses and on the Open Educative Resources (OER) development (RUA).

\section{Sending materials for the RUA}

Any OER can be uploaded to the RUA through a Web Page form. In order to ease communication and take advance of the online infrastructure, all the interactions between the users and the RUA is virtual. The RUA's Web Page has a section to login. All UNAM researchers and teachers are allowed to login. Once logged in, there is a "suggest resources" option to suggest materials. All OER materials must be provided with: a title, a short description, 
the relation with any of the UNAMs' curricula, and the apps and/or documents (or links to them). Once the request is uploaded, DGTIC analyzes and verifies that the OER complies the copyrights, under the law - Ley Federal de Derecho de Autor and the UNAM editorial guidelines (UNAM, 2007).

\section{Validation}

Evaluating the pertinence of contents is a complex task. This task might be unnecessary in the near future, given that all materials are generated by the university members. However, the learning process from DGTIC when building collaborations among professors has motivated them towards content validation. Content validation has allowed to strengthen the academic collaboration within the institutions and members, to extend current collaborations, and even to build new partnerships.

Validation is conducted by an Academic Committee. Each school or institution designs an ad-hoc academic body in charge with validating the OER. The procedure includes a meeting with DGTIC personnel to set goals and mechanisms needed when validating OER. The procedure includes:

- An evaluation, emitted from each participant professor.

- A collegiate judgment.

The process is reported online and the chief in charge of the institution is responsible to follow up the procedure. Final decision is registered in RUA's Web Page (UNAM, 2016).

\section{Publication}

Once the validation is done, there is a group of normalization and classification processes that must be met prior publication. Normalization includes sometimes, the reconfiguration of materials to forms, styles, orthography, and grammar reviews. This reconfiguration is mainly done to achieve a standard on quality, regarding readability and easiness to display. None of the contents are modified. The classification includes the adjustment of an international standard: LOM (IEEE Std 1484.12.1 for Learning Object Metadata); this adjustment is called "LOM-RUA". LOM-RUA is a metadata that describes features and relevant data about the OER. The metadata are grouped into eight categories: General, Lifecycle, Technical information, Educative uses, Rights, Classification, and Control and Captures (RUA 2017).

\section{Spread, divulgation and use on the classrooms}

The fifth and last process is may be the largest challenge to the DGTIC personnel. The final goal of this effort is to achieve a full appropriation of the RUA contents by professors and students, mainly in the classrooms. This activity involved the willingness and decision from each teacher and researcher from every school and course to use OER and to encourage the students to earn knowledge; both elements out of the scope from the DGTIC. Consequently, to set spreading and use mechanisms is, in principle, a task that must be done by all (the teaching and learning actors, and the DGTIC personnel).

To date, DGTIC is conducting a project under the research-action methodology that supports the constructs and a model building that helps the use of materials in the classroom.

\section{Conclusions}

Teachers and researchers are, without doubt, the ones who better identify the needs, strengths, and obstacles on the teaching and learning process due to their responsibility on giving a course. Here we want to stress that teacher participation process must be incentivized right from the design of educative tools. Open Educative Resources development by teacher's communities promotes the intervention of the educators' groups on the design, elaboration, publication, and sharing materials of university's curricula. This promotion can encourage the utilization of each OER: if it has enough modularity to adapt at any course and learning 
objectives. And second: each OER would be strong enough to transmit a clear and effective knowledge.

Teachers participation is the key to overcome resistance to change problems. However, we must be aware that, in some cases, there are needs to be covered prior to the use of an OER. We must have the proper technologies (ICT), knowledge, and skills that allow the OERs use. This use includes building tools with relevant features to get the message thru and transmit the knowledge centered in the learning and teaching process. Those lacks make it harder for the production and use of virtual educative resources.

In UNAM case, participatory approach has encouraged participation and interest of teachers to learn and utilize OER into their classrooms. The Academic Program (PAPIME) to develop digital resources has had a good reception with teacher participation increasing each year. Therefore, universities must motivate the teachers work in creation and utilization of educative resources, associated with education budgets with the same goal.

At the moment, DGTIC is working in developing teachers' participation mechanisms. Currently, there is a consideration about how to measure suitable constructs throughout a technological appropriation model (for instance Saga and Zmud, 1999) and to the formulation of the use spreading strategy. Given the UNAMs' size, and the amount of institutions and curricula, it is very challenging for DGTIC personal alone to build the RUA. It is possible that in the near future, the OER integration and creation for each course will be done by each school and department.

\section{Acknowledgment}

To Dr. Guillermo Rodríguez, Mta. Rebeca Valenzuela and their RUA team from DGTIC-UNAM to provide all information to analyze and to develop this paper.

\section{Bibliography}

1. Albors, J., Ramos, J., \& Hervas, J. (2008). New learning network paradigms: Communities of objectives,. International Journal of Information Management(28), 194-202.

doi::10.1016/j.ijinfomgt.2007.09.006

2. Argyris, C. (1992). On organisational learning. Oxford: Blackwell Publishers.

3. Avello, R., \& Duart, J. (2016). Nuevas tendencias de aprendizaje colaborativo en e-learning. Claves para su implementación efectiva. Estudios pedagógicos, 42(1). Obtenido http://dx.doi.org/10.4067/S071807052016000100017

4. Badia, A., \& García, C. (2006). Incorporación de las TIC en la enseñanza y el aprendizaje basados en la elaboración colaborativa de proyectos. Revista de Universidad y Sociedad del Conocimiento, $3(2)$.

5. Bandura, A. (1977). Self-efficacy: Toward a unifying theory of behavioural change. Psychological Review, 84(16), 191215.

6. Bracho, F. (2017). ¿Qué es la RUA?. Entrevista al Dr. Felipe Bracho. UNAM FES Acatlán, CETED. Obtenido de http://mediacampus.cuaed.unam.mx/node $/ 5701$

7. Castillejos, J., \& Peñaloza, M. (2016). Plataforma institucional para promover el Acceso Abierto a los contenidos digitales: Toda la UNAM en Línea. Sexta Conferencia de Directores de Tecnología de Información, TICAL 2016. Buenoa Aires, Argentina: Red Clara. Obtenido de http://tical2016.redclara.net/index.php/es /component/tags/tag/46-conferencia-tical

8. Crosby, L., \& Muehling, D. (1983). External Variables and the Fishbeinmodel: Mediation, Moderation, Or Direct Effects? Advances in Consumer Research(10), 9499. 
9. CUAED-UNAM.

(2012-1016).

Diplomado en educación a distancia. Docencia para la educación a distancia. (C. d. Distancia, Ed.) CDMX: UNAM.

10. DGAPA-UNAM. (2017). Programa de Apoyo a Proyectos para la Innovación y Mejoramiento de la Enseñanza (PAPIME). (P. d. (DGAPA), Productor) Recuperado el Mayo de 2017, de Universidad Nacional Autónoma de México: http://dgapa.unam.mx/

11. EcuRed. (2015). Plataformas educativas. Recuperado el 10 de Enero de 2016, de Enciclopedia colaborativa en la red cubana: http://www.ecured.cu/index.php/Platafor mas_Educativas

12. Festinger, L. (1957). A Theory of cognitive dissonance. Stanford, CA: Stanford University Press.

13. Fishbein, M., \& Ajzen, I. (1975). Belief, Attitude, Intention, and Behavior: An Introduction to Theory and Research. Reading, MA: Addison-Wesley.

14. Gvelesiani, I., \& Javakhishvili, I. (2013). Ancient and Contemporary Educational Systems. European Scientific Journal, 4(Special), 1857-7881.

15. H. Congreso de la Unión, C. (2014). Del Acceso Abierto, Acceso a la Información Científica, Tecnológica y de Innovación y del Repositorio Nacional. En Ley de ciencia y tecnología. CDMX: DOF 08-12-2015.

16. ITESM. (2017). Aprendizaje Colaborativo. Técnicas Didácticas. Instituto Tecnológico y de Estudios Superiores de Monterrey. Dirección de Investigación e Innovación Educativa. Obtenido de http://www.itesca.edu.mx/documentos/de sarrollo_academico/metodo_apr

17. Kahiigi, E., Ekenberg, L., Danielson, M., Hansson, H., \& Tusubira, F. F. (2008). Exploring the e-Learning State of Art. The Electronic Journal of e-Learning, 6(2), 77 88. Obtenido de www.ejel.org
18. Kremer, M., Brannen, C., \& Glenner, R. (2013). The challenge of education and learning in the developing world. Science, , 340(6130), 297-300.

19. Kucharčíková, A., \& Tokarčíková, E. (2016). Use of Participatory Methods in Teaching at the University. The Online Journal of Science and Technology, 6.

20. Mendoza, J. (2017). Participaciones en el foro universitario. "La UNAM y los Desafíos de la Nación" sobre el tema de educación "Los temas críticos de la educación en México: Evaluación, financiamiento y equidad". CDMX, México: UNAM. Recuperado el 2017, de https://www.youtube.com/watch?v=0kV7 3gfXVWo

21. Ming-Sum, T., \& Tsui, A. (2007). Participative Learning and Teaching Model: The Partnership of Students and Teachers in Practice Teaching. The International Journal Social Work Education, 26(4).

22. Muhlenbrock, M. (1999). A system for Analyzing Collaborative problem solving. On line. Obtenido de http://citeseerx.ist.psu.edu/viewdoc/dow nload;jsessionid=D981C0EDF2B27AF1C89 8EE7C750583C2?doi=10.1.1.25.8372\&rep $=$ rep $1 \&$ type $=$ pdf

23. OCDE. (2016). Panorama de la Educación 2016: Indicadores de la OCDE. OCDE. Obtenido de https://www.oecd.org/mexico/Educationat-a-glance-2015-Mexico-in-Spanish.pdf

24. OCDE. (2017). Panorama de la educación. Indicadores de la OCDE 2017. Ma: MINISTERIO DE EDUCACIÓN, CULTURA, ESPAÑA.

25. OECD. (2012). Equity and Quality in Education: Supporting Disadvantaged Students and Schools. OECD Publishing.

26. OECD. (2017). Giving Knowledge for Free the Emergence of Open Educational Resources. Organisation for Economic CoOperation and Development, Centre for Educational Research and Innovation. 
27. Suber, P. (2009). Timeline of the Open Access Movement. Formerly called the Timeline of the Free Online Scholarship Movement. Obtenido de http://legacy.earlham.edu/ peters/fos/ti meline.htm

28. UNAM. (2011). Plan de Desarrollo Institucional (PDI) 2011-2015. Dr. José Narro. Ciudad Universitaria, CDMX: UNAM. Recuperado el 2017, de http://www.planeacion.unam.mx/consulta /PlanDesarrollo2011-2015.pdf

29. UNAM. (2015). Acuerdo por el que se establecen los Lineamientos Generales para la Política de Acceso Abierto de la Universidad Nacional Autónoma de México. Gaceta UNAM, 10 de septiembre de 2015. C: UNAM

30. UNAM. (2015). Plan de Desarrollo Institucional (PDI) 2015-2019. Ciudad Universitaria, CDMX: UNAM. Obtenido de http://www.rector.unam.mx/doctos/PDI2015-2019.pdf

31. UNAM. (2016). Red Universitaria de Aprendizaje (RUA). (U. N. México, Editor, \& DGTIC, Productor) Recuperado el Abril de 2017, de http://www.rua.unam.mx/

32. UNAM. (2016). Red Universitaria de Aprendizaje (RUA), ¿Qué es y cómo funciona? Universidad Nacional Autónoma de México. DGTIC Documento de trabajo.

33. UNAM. (2016). Red Universitaria de Aprendizaje (RUA), Colegio de Ciencias y Humanidades. (U. N. trabajo, Ed.) Ciudad Universitaria, CDMX: UNAM.

34. UNAM. (2017). La UNAM en números, 2016-2017. Recuperado el Junio de 2017, de Portal de Estadística Universitaria.
Coordinación de Sistemas, DGPL: http://www.estadistica.unam.mx/numeral ia/

35. UNAM. (s.f.). Toda la UNAM en línea. Recuperado el Junio de 2017, de http://www.unamenlinea.unam.mx/

36. UNAM, L. t. (2007). Edición y derecho de autor en las publicaciones de la UNAM. (UNAM, Ed.) Recuperado el July de 2017, de Edición UNAM: http://www.edicion.unam.mx/html/4_6.ht $\mathrm{ml}$

37. UNESCO. (2008). Etapas de las Sociedades del Conocimiento. Material de referencia para comunicadores. InterPress Service.

38. UNESCO. (2008). Etapas hacia las Sociedades del Conocimiento. Uruguay: InterPress Service.

39. UNESCO. (2015). Institute for Statistics. UIS.Stat Database; Education Theme. UNESCO. Obtenido de http://www.uis.unesco.org

40. UNESCO. (2017). Recursos Educativos Abiertos. Comunicación e información de la UNESCO, Sección: Acceso al conocimiento. Obtenido de http://www.unesco.org/new/es/communi cation-and-information/access-toknowledge/open-educational-resources /

41. Van der Krogt, F. (1998). Learning Network Theory: The Tension Between Learning Systems and Work Systems in Organizations. Human Resource Development, 9(2).

42. Vigotsky, L. (1978). Mind in Society. The development of Higher Psycological Processes. Harvard University Press. 